\title{
Chapter 16 \\ Commentary: The Blauzone Rheintal \\ from a Hydrological \\ Perspective-A Transboundary \\ Flood-Mitigation Solution in a Large \\ Gravel-Bed River Basin
}

\author{
Nejc Bezak, Mojca Šraj and Matjaž Mikoš
}

\section{Hydrological Perspective: Reflection and Open Questions}

The case of the Alpine Rhine (Alpenrhein in German) upstream of the Lake of Constance (Bodensee in German) is a good example for a large alpine gravel-bed river that is shared by several countries and for high population density from the Alps perspective. Bringing into focus also common transboundary issues in water management of large basins shared by neighbouring countries and presenting open dilemmas due to different water management and spatial planning policies and procedures in these countries, the presented work (i.e., named "Blauzone Rheintal" in the book chapter written by Löschner et al. this volume) can be regarded as an advanced case study. Why? Firstly, the Alpine Rhine was heavily regulated in the past (Meyer-Peter and Lichtenhahn 1963; Lichtenhahn 1972). Secondly, the Alpine Rhine is a part of the large European Rhine River Basin, where in the field of water management the international cooperation is lead by the International Commission for the Protection of the Rhine (ICPR 2018), and between Switzerland and Austria, since 1892, the Internationale Rheinregulierung (IRR 2018a). Over the decades, these different international bodies have prepared very good hydrologic, hydraulic, and other flood-hazard related data, models and concepts such as the 2005 Alpine Rhine concept (IRKA and IRR 2005) and the Rhesi flood protection project (IRR 2018b) that presented a very good basis for the implementation of the Blauzone. As noted by Löschner et al. (this

N. Bezak (凶) $\cdot$ M. Šraj $\cdot$ M. Mikoš

Faculty of Civil and Geodetic Engineering, University of Ljubljana, Ljubljana, Slovenia

e-mail: nejc.bezak@fgg.uni-lj.si

M. Šraj

e-mail: mojca.sraj@fgg.uni-lj.si

M. Mikoš

e-mail: matjaz.mikos@fgg.uni-lj.si

(C) The Author(s) 2019

T. Hartmann et al. (eds.), Nature-Based Flood Risk Management on Private Land, https://doi.org/10.1007/978-3-030-23842-1_16 
volume), the Blauezone is part of the Rhesi flood protection project. Rhesi is flood protection project that can be regarded as the first major phase in the implementation of the Alpine Rhine development concept (IRR 2018b). Moreover, the Blauezone (blue zone) was implemented based on the spatial plan named Grünzone (green zone) that was developed almost 50 years ago and secured areas for agricultural purpose in the Alpine Rhine valley (Löschner et al. this volume). These efforts have sought regional flood risk reduction in the Alpine Rhine valley by implementing different structural and non-structural measures (Stalzer 2007, 2008). From a hydrological perspective, for the development of models and concepts very good input data (e.g., appropriate density of rainfall gauging stations, high-frequency measurements) is needed, and state-of-the-art methods should be used with the consideration of uncertainty in the model results. Morevoer, possible climate change or variability impacts should also be taken into consideration in hydrological investigation.

The Alpine climate zone is an area with very high soil loss rates due to water erosion because of the combined effect of topography (i.e., steep slopes) and rainfall erosivity (e.g., summer thunderstorms) (Panagos et al. 2015). Moreover, in areas located above the tree line, the vegetation cover is sparse, which, in combination with other erosion types (e.g., ice erosion), additionally increases erosion rates. Thus, high soil erosion rates and intense and complex sediment transport processes can be expected in Alpine rivers, which means that not only floods but also a combination of sediment transport and corresponding morphological processes can endanger people leaving in the Alpine valleys (Fäh et al. 2012). The Alpine Rhine was known as the largest torrent in Europe, and, after several extreme events that occurred between 1801 and 1900, the IRR was established (Fäh et al. 2012). First measures that were taken did not take an interdisciplinary approach and were not able to solve the flooding issue in the valley. They also influenced bed-load balance and groundwater level (Zarn 2008; Fäh et al. 2012). However, newer interdisciplinary approaches also considered bed load management in combination with other aspects, such as ecology and development of recreational activities (IRKA and IRR 2005). In the past, due to gravel mining, at some sections, the river bed had decreased by almost $5 \mathrm{~m}$ between 1941 and 1995 (Zarn 2008). The eroded material was deposited in the Lake of Constance and led to delta growth (Zarn 2008). At the moment, the river bed at the international section of the Alpine Rhine is near a stable state of equilibrium (Zarn et al. 1995; Fäh et al. 2012), which means that a potential change in river cross-section can lead to aggradation or degradation of the river bed, which can also have an impact on flood safety. Thus, other approaches, such as spatial planning, are needed in order to ensure flood safety in this area. The importance of erosion and sedimentation processes in river basins was also underlined by the International Sediment Initiative (ISI 2018) launched by the United Nations Educational, Scientific and Cultural Organization (UNESCO) International Hydrological Programme (IHP) in 2004. Therefore, it is important to stress that, from a hydrological point of view, in such a large alluvial river as the Alpine Rhine, flood risk assessment and countermeasures must also take river sediments and estimation of sediment budget of a river into account (Stalzer 2007, 2008). 
Changing flood peaks by controlled overflow of dikes and routing flood waters into designated flood areas (agricultural land, riverine forests, wetlands, ...) may change the sediment regime in the main watercourse and, in flooded areas, may cause local soil erosion problems and/or accumulation of fine sediments by settling of suspended sediments in flood waters. Furthermore, from an engineering perspective, the design of water routing to the designated flood areas (i.e., hydro-technical structures used for water diversion) is a complicated task since the water velocities during the flood events are high (cca. between 1 and $5 \mathrm{~m} / \mathrm{s}$ ) when these areas are actively used. In combination with high bed and suspended load transport during flood events, this makes it difficult to predict water levels (i.e., large uncertainty) and consequently predict water movement on the designated flood areas (i.e., issue of effective use of flood volume). Moreover, this kind of structures also cannot be tested before the flood event (i.e., operational testing). The issue of flood damages on the designated flood areas determined through spatial planning procedures must be regulated in advance. Therefore, how spatial planning of flood risk reduction measures are conveyed to stakeholders is of paramount importance as well as how flood risk dialogue is conceptualised and put into practice. The Blauzone Rheintal is a good example, how, as a part of advanced water management concepts for flood risk reduction in the Alpine environment, spatial planning should be applied as a tool to bring such concepts to life. From this perspective, it is a case study that discusses the structure and responsibilities on a state and regional level in spatial planning procedures that are not the same across multiple countries. How adaptive water management concepts are turned into practice is also to a large extent dependent on how land use policy is regulated by spatial planning acts and who is responsible for planning-the state or local communities (municipalities). In the field of water management, the European Water Directive and the Flood Directive ask for an integrated basin-level approach in flood hazard assessment and flood risk reduction policy (for the Alpine Rhine see Stalzer 2007, 2008). The way to fulfil planned flood risk reduction measures at different scales is to have clear spatial planning instruments (procedures, regional and local plans) that are capable of effectively implementing water management measures.

Another process that is important from a hydrological perspective and was also investigated and considered in the Alpine Rhine case study is groundwater recharge (e.g., Zarn 2008). Changes in the Alpine Rhine River bed in the previous century also influenced the groundwater level that decreased in the past (Zarn 2008). Since groundwater is an important source of drinking water for almost half a million inhabitants in the Alpine Rhine valley (Zarn 2008), the proposed and implemented flood protection measures that stabilised the river bed consequently have a positive impact on groundwater storage. Moreover, the use of designated flood areas (i.e., Blauzone) for flood protection also has a positive impact on the groundwater storage since the flood water is not routed directly to Lake Constance but it is kept in the Alpine Rhine catchment for a longer time period (i.e., infiltration to the soil and groundwater recharging). 


\section{Transferability Across Scales, Places and Disciplines and Final Remarks}

The Sava River (part of the Danube River Basin) is another case study where sediment management is considered as part of the FRM plan. In the Sava River, the efforts for integrated water management in this basin are led by the International Sava River Basin Commission (ISRBC 2018). The ISRBC also prepared the Sava River Basin Management Plan (Sava RBMP 2018) and the FRM Plan in the Sava River Basin (Sava FRMP 2018). However, the implementation of spatial planning measures is up to countries and cannot be fully regulated on the international scale.

Moreover, the described Alpine Rhine case study (Zarn 2008; Löschner et al. this volume) is aligned with the integrated water management policy and is especially pertinent to the flood risk reduction policy that calls for "more room for water"which has been more and more widely accepted; the Dutch project "Room for the River" may serve as an example here. In 2006, the Dutch Cabinet proposed the Spatial Planning Key Decision (SPKD) - a design plan for more highly innovated structures and the modification of existing structures in the immediate floodplains of four major Dutch rivers - the project was executed from 2006 to 2015 (Room for the River 2018).

It is clear that the Rhesi flood protection project (part of which is a Blauzone regional planning instrument) can be regarded as an interdisciplinary approach that considered numerous aspects of flood protection (e.g., planning of recreation activities in the area, sediment transport, groundwater storage, etc.). Moreover, intense transnational cooperation was also needed to implement Rhesi and Blauzone. Thus, the presented case study could be transferred to different areas and to smaller and larger catchments than the Alpine Rhine catchment. In a different situation, the area along the river could be more densely populated, which would enable implementation of measures such as Blauzone regional planning that was based on the older measure that secured agricultural land along the river (Löschner et al. this volume). Moreover, this kind of approach is probably not very suitable for smaller Alpine rivers with significant torrential characteristics, because this kind of river is usually located in narrow valleys without much free space for dedicating land to water. Furthermore, torrents have a very fast response; this complicates the design of designated flood areas. Finally, the presented approach can be regarded as state-of-the-art and can serve as a role model for other alpine catchments.

Acknowledgements The results of the study are part of the research Programme P2-0180: "Water Science and Technology, and Geotechnical Engineering: Tools and Methods for Process Analyses and Simulations, and Development of Technologies" that is financed by the Slovenian Research Agency (ARRS).

Open access of this chapter is funded by COST Action No. CA16209 Natural flood retention on private land, LAND4FLOOD (www.land4flood.eu), supported by COST (European Cooperation in Science and Technology). 


\section{References}

Fäh R, Weiss M, Hengl M, Dietsche D, Boes R (2012) Alpine Rhine river-sustainable flood protection measures between the levees. In: 12th congress interpraevent 2012 proceedings, Grenoble, France, pp 23-26, April 2012

ICPR (2018) International Commission for the Protection of the Rhine. DIALOG. www.iksr.org. Accessed 8 Aug 2018

IRKA, IRR (2005) Entwicklungskonzept Alpenrhein - Kurzbericht. DIALOG. http://www. rhy-faescht.org/fileadmin/user_upload/2015/rhyfaescht-data/b_documents/IRKA_EKA_ Alpenrhein_2005_kurz.pdf. Accessed 8 Aug 2018

ISI (2018) International Sediment Initiative. DIALOG. http://his.irtces.org/isi/. Accessed 8 Aug 2018

ISRBC (2018) International Sava River Basin Commission. DIALOG. www.savacommsion.org. Accessed 8 Aug 2018

IRR (2018a) Internationale Rheinregulierung. DIALOG. www.rheinregulierung.org/. Accessed 8 Aug 2018

IRR (2018b) Rhesi - Rhein, Erholung und Sicherheit. Internationale Rheinregulierug. DIALOG. http://www.rhesi.org/. Accessed 8 Aug 2018

Lichtenhahn C (1972) Flussbauliche Probleme am Rhein zwischen Reichenau und dem Bodensee im Wandel der Zeit. Wasser- und Energiewirthschaft 64(10-11):341-353

Meyer-Peter E, Lichtenhahn C (1963) Altes und Neues über den Flussbau. Eidg. Departement des Innern, Veröffentlichungen des Eidg. Amtes für Strassen- und Flussbau, Bern

Panagos P, Borrelli P, Poesen J, Ballabio C, Lugato E, Meusburger K, Montanarella L, Alewell C (2015) The new assessment of soil loss by water erosion in Europe. Environ Sci Policy 54:438-447

Room for the River (2018) Room for the River for a safer and more attractive river landscape. DIALOG. https://www.ruimtevoorderivier.nl/english/. Accessed 9 Aug 2018

Sava FRMP (2018) Flood risk management plan in the Sava River Basin. DIALOG. http://www. savacommission.org/sfrmp/en/. Accessed 8 Aug 2018

Sava RBMP (2018) Sava River Basin Management Plan. DIALOG. http://www.savacommission. org/srbmp/en/. Accessed 8 Aug 2018

Stalzer W (2007) Alpenrhein 2100 - Vom Gestern zum Morgen im Alpenrheintal. Oesterr Wasser Abfallwirtsch 59(7-8):23-28

Stalzer W (2008) Der Alpenrhein - Versuch einer nachhaltigen Entwicklung für den größten alpinen Wildfluss. Oesterr Wasser Abfallwirtsch 60(5-6):73-79

Zarn B (2008) Development concept river Alpine Rhine. In: 11th congress interpraevent 2008 Proceedings, Dornbirn, Austria, pp 26-30, May 2008

Zarn B, Oplatka M, Pellandini S, Mikoš M, Hunziker R, Jäggi M (1995) Geschiebehaushalt Alpenrhein. Mitteilungen der VAW 139, ETH Zürich

Nejc Bezak Ph.D., is Assistant Professor at the Faculty of Civil and Geodetic Engineering, University of Ljubljana. He is member of the UNESCO Chair on Water-Related Disaster Risk Reduction. His main research interests are various hydrology sub-fields such as statistical hydrology (e.g., multivariate analyses, trend detection, design discharge determination, flood risk assessment), hydrological and hydraulic modelling, data-analyses, climate change investigation, field measurements.

Mojca Šraj Ph.D., is Associate Professor of Hydrology at the Faculty of Civil and Geodetic Engineering, University of Ljubljana and a member of the UNESCO Chair on Water-Related Disaster Risk Reduction. Her main research interests include applied hydrology, rainfall-runoff modeling, extreme events analyses, flood risk assessment, forest hydrology, time series analyses and 
climate change. She has published more than 90 scientific papers in the area of hydrology and water resources.

Matjaž Mikoš dr. sc. techn. ETH Zurich, is Professor of Hydrology and Hydraulic Engineering, currently Dean of the Faculty of Civil and Geodetic Engineering, University of Ljubljana, and Head of the UNESCO Chair on Water-Related Disaster Risk Reduction. He is Member of the INTERPRAEVENT Scientific-Technical Board; he served two terms as its head. He is expert in applied hydrology, sediment management, river engineering, torrent control, and flood and landslide risk management.

Open Access This chapter is licensed under the terms of the Creative Commons Attribution 4.0 International License (http://creativecommons.org/licenses/by/4.0/), which permits use, sharing, adaptation, distribution and reproduction in any medium or format, as long as you give appropriate credit to the original author(s) and the source, provide a link to the Creative Commons license and indicate if changes were made.

The images or other third party material in this chapter are included in the chapter's Creative Commons license, unless indicated otherwise in a credit line to the material. If material is not included in the chapter's Creative Commons license and your intended use is not permitted by statutory regulation or exceeds the permitted use, you will need to obtain permission directly from the copyright holder. 